\title{
Karel Hrubý - spiritus agens politického a kulturního zápasu
}

\author{
Aleš Prázný \\ Univerzita Pardubice, $\check{C} R$
}

PRÁZNÝ, A.: Karel Hrubý - Spiritus Agens of Political and Cultural Struggle

Philosophica Critica, vol. 7, 2021, no. 2, ISSN 1339-8970, pp. 5-16.

The article portraits Karel Hrubý as an engaged thinker, intellectual and a politician, who by his theory and praxis had responded to the key events of Czechoslovak history of the second half of the 20th century. Hrubý's political and cultural endeavour for social and humane politics and his reflections on totalitarianism of the communist regime in former Czechoslovakia represent a cardinal idea of the paper. Hrubý is introduced as a pivotal figure of Czechoslovak exile. This text reminds us of major thinkers, who oriented Karel Hrubý on the way of culturally and politically determined politics, and is further dedicated to polemics against representatives of a revisionist concept of modern history.

Keywords: Karel Hrubý - Masaryk - Democracy - Freedom Stalinism - Critique of Marxism - Ideologization of science Charter 77 - Revisionism

„Bez filosofického základu a perspektivy, která z něj vychází, je politika jen zápasem o výhody pro některé, zápasem o moc a majetky. Obávám se, že se tomuto stavu dost nebezpečně přibližujeme.“1

\section{Úvod}

Základní postoj k věcem veřejným a k politice si Karel Hrubý (1923-2021) odnesl už z rodiny a prostředí, v němž vyrůstal. Když byl šestnáctiletým soustružnickým učněm ve Škodovce, oslovil jej svým spisem Zdravý rozum (1776) americký intelektuál Thomas Pain - a zanechal v něm výrazný dojem. Pain v tomto spise odmítá monarchii jako instituci odporující

1 Hrubý, K., „Žijeme ve slabé společnosti“, rozhovor s A. Prázným v Lidových novinách 24. ř́ina 2014, s. 13. 
přirozeným právům. Painova práce Hrubého upozornila na politickou filosofii Johna Locka, který už o sto let dříve zdůvodňoval přirozenost svobody, rovnosti a lidských práv pro každého člověka. (Hrubý 2014,13) Politické myšlení už jej posléze provázelo celý život. Později po studiu češtiny a filosofie na Filosofické fakultě University Karlovy (1945-1949) působil v letech 1950 až 1955 jako profesor na gymnasiu ve Stříbře, v Domažlicích a na Pedagogické škole v Plzni. V roce 1955 byl zatčen za „protistátní činnost“ a odsouzen k deseti letům vězení. „Kriminál je taková životní cézura, to člověk nemůže popřít. Všechno, co bylo před tím pozitivní a co dělalo váš život pěkný, je rozmetáno. Najednou jste zbaven rodiny, jste zbaven možnosti studovat, jste zbaven komunikace s přáteli a ocitnete se za ostnatým drátem." (Hrubý 2015, 121) Po propuštění na amnestii roku 1960 pracoval jako brusič kovů v Plzni (do r. 1967), následně osm měsíců pracoval jako sociolog ve Výzkumném ústavu výrobního družstevnictví v Praze. Roku 1968 se podílel na pokusu obnovy Československé sociální demokracie (Hoppe 2009). Po srpnové invazi emigroval v září do Švýcarska, kde se usadil v Basileji. Zde v letech 1968 až 1988 pracoval jako sociolog ve farmaceutické společnosti CIBA-GEIGY, která mu poskytovala dostatek možností a zdrojů, z nichž mohl podporovat kulturně politickou činnost v exilu (Tomeš 2005, 67).

\section{Určující impulzy}

Hrubého myšlení a život nejvíce ovlivnil T. G. Masaryk, který jej „svou humanitní morálkou a demokratickým pojetím odpovědného občanství utvrdil v příklonu k sociální demokracii“ (Hrubý 2018, 44). Každé odpoledne, když přišel Hrubý jako učeň ze Škodovky, spěchal do studijní knihovny, kde tehdy - za války a hitlerovské okupace - mu knihovníci potajmu půjčovali Masarykovy spisy ke studiu. První kniha, jíž prostudoval, byla Moderní člověk a náboženství. Masaryk se v ní zamýšlí nad smyslem života individuálního člověka. Hrubý zde u Masaryka našel odkazy k dalším filosofům a literátům, kteří jej potom provázeli celým životem - Hume, Kant, Comte, ale také Goethe, Dostojevskij, Tolstoj a další. V roce 1941 Hrubý odešel ze Škodovky od výroby kanonů pro Wehrmacht do učitelského ústavu, věděl, že se chce stát učitelem. Tehdy přišla na řadu Masarykova Česká otázka a Ideály humanitní (Hrubý 2014,13). Později to byla především humanitně zaměřená politika, co Hrubého na Masarykovi oslovilo. Humanita byla Masarykovi odpovědí na českou otázku. Humanita jako uskutečňování dobra je úkolem pro reflexivní i praktickou činnost.

Hrubý si byl vědom toho, že právě humanitním programem Masaryk oslovil značnou část české veřejnosti a odpověděl na otázku smyslu českých 
dějin jako naplňování ideálu humanity (Hrubý 2018, 23). Od Masaryka se naučil, že zápas o svobodu se musí vést nejen politicky, ale i sociálně a kulturně. Masarykovské ideály se pro Hrubého staly oporou a štítem v době, kdy komunistická ideologie prostoupila značnou část české společnosti a utvářela její vidění světa. Na rozdíl od komunistů, kteří vyžadovali podřízenost straně i navzdory svému svědomí, zdůrazňoval Masaryk po kantovsku, že „člověk člověku se nikdy nesmí stát pouhým nástrojem“ (Hrubý 2018, 44).

Na Masarykův důraz na kulturní a sociální práci Hrubý prakticky navázal později ve švýcarské emigraci (od září roku 1968), kde se politicky zapojil do Rady svobodného Československa (od r. 1975 člen předsednictva), sociálně do exilové sociální demokracie (jejímž byl v letech 19721983 místopředsedou, v letech 1983-1989 generálním tajemníkem a v letech 1989-1995 posledním předsedou) a Socialistické internacionály. Kulturně působil ve švýcarské sekci Československé společnosti pro vědu a umění (SVU) a v letech 1982-1992 byl redaktorem její revue Proměny (Tomeš 2005,66$)$. Pod jeho vedením patřila právě švýcarská pobočka SVU v Evropě k nejaktivnější. Jeho přítel Jaroslav Krejčí připomíná Hrubého význam právě jako předsedy švýcarské sekce SVU a redaktora Proměn. Poukazuje na roli, kterou sehrála kulturně politická činnost „našich Helvetů" pro Československo i po jeho osvobození, a právě Karla Hrubého považuje za spiritus agens těchto činností (Krejčí 2006, 138).

Rozhodujícím impulsem pro Hrubého pojetí sociální problematiky byla Otázka sociální, v níž Masaryk rozvinul principy humanity proti marxistické materialistické doktríně a morálku proti mechanismu hospodářských faktorů. Proti anonymitě sil, jež měly předurčovat vývoj společnosti, postavil svobodnou vůli člověka; autonomní lidský subjekt zde stojí proti fatální „zákonitosti“ historického materialismu. To bylo blízké i Hrubého pojetí. Trilogie Rusko a Evropa, v níž Masaryk interpretoval charakter a vliv Ruska na budoucnost Evropy, rovněž Hrubého výrazně ovlivnilo. Poslední dvě díla Hrubý četl už jako student filosofie na Karlově univerzitě v prvních letech po druhé světové válce. Masaryk mu tak poskytl všestranné rozhlédnutí po problematice, která se dotýkala československého národního osudu i Hrubého tehdejších zájmů.

Kromě Masaryka pak Hrubého ovlivnili Emanuel Rádl, zejména důrazem na význam morálky a promýšlení politických a sociálních aspektů národního života, Eduard Bernstein, který podle Hrubého „nemilosrdně korigoval“ Marxovy nesprávné prognózy, a Karl Popper svou kritikou takzvaných uzavřených společností, jako byly diktatury 20. století. Hrubý viděl jasně, že Bernsteinův revizionismus a Masarykův etický socialismus dráždily stoupence leninské revoluční teorie. Ve svém pojednání 
o Bernsteinovi a Masarykovi pak Hrubý upozornil na to, že oba docházejí v kritice marxismu k podobným závěrům: oba zpochybňují materialismus, odmítají dialektiku, katastrofismus a revoluci, a proti fatalisticky působícím anonymním silám, zdůrazňují nezastupitelnost osobní morálky (Hrubý 2018, 143).

Významný myšlenkový vliv na Karla Hrubého představoval i filosof Jan Patočka - svým úsilím o náročné poznání podstaty světa a role člověka v něm, jak ho naznačil Edmund Husserl a jeho fenomenologičtí pokračovatelé. Patočka působí dle Hrubého trvale příkladným spojením filosofie a boje za svobodu a solidaritu, který se nejvýrazněji projevil v aktivitě Charty 77. Hrubý připomíná, že šlo původně o mravní aktivitu a zmiňuje v této souvislosti dva Patočkovy články: 0 povinnosti bránit se proti bezpráví a Co můžeme očekávat od Charty 77 (Hrubý 2018,108). Patočka definoval chartu morálním a pedagogickým rozměrem, jež jsou dle Hrubého nezbytné pro humanitní identitu národa. Jakkoli charta nechtěla být politickou akcí, a mnozí její příznivci vyznávali apolitický charakter charty, Hrubý poukázal na to, že funkčně plní opoziční roli a že „charakter tohoto manifestu byl nepochybně politický. Odmítala se v něm nadvláda komunistické strany a požadovala se socialistická demokracie a humanita navazující na dobré tradice naší země“ (Hrubý 1997a, 47). Význam Charty 77 viděl Hrubý nejen v povzbuzení „vyšší mravní normy v národě, tlačeném do přikrčenosti, oportunity a uzavřenosti“(Hrubý 2018, 116), ale také $\mathrm{v}$ tom, že se její signatáři přihlásili k tradici počátků dělnického a socialistického hnutí, jehož principům komunistická diktatura zůstávala mnoho dlužna. Hrubý připomíná, co zůstává často na okraji, a sice že Charta 77 směřovala k demokratickému socialismu, který na rozdíl od komunistické diktatury odmítal autoritativní prvky a monopolizaci moci; šlo jí o demokratické svobody a občanská práva, jak je už ve svém počátku formulovalo české dělnické hnutí (Hrubý 2018, 110).

\section{Zápas o politickou a kulturní orientaci}

Některé z mnoha motivů k poválečnému př́klonu československého obyvatelstva ke komunistům spočívaly podle Karla Hrubého ve zklamání z minulosti a z pochybnosti o vývoji dějin. Konkrétně šlo o šok z velké ekonomické krize 30. let a ze selhání parlamentní demokracie v době Mnichova (Hrubý 2018, 34). Zatímco německý nacismus prosazoval především expanzi a prosperitu vlastního národa a zničení rasově vytipovaných skupin, ruský bolševismus upřednostňoval univerzální cíle, které měly - přes tř́ídní boj - vést k harmonii lidstva. Podle Hrubého komunismus nelákal ani tak svou marxistickou teorií či leninskou ideologií, spíše vstoupil do našich 
dějin jako „romantické pokušení“ komunistické víry (Hrubý 2018, 162), jemuž mnozí podlehli.

Horlivost podílet se na veřejném dění a vítězit spolu s těmi, kdo stojí na „správné straně dějin“, přiměla řadu mladých lidí ke vstupu do KSČ. Představa, že zejména po válce rozpoznali, kam dějiny směřují, je fascinovala. Byli to rovněž mladí intelektuálové, kdo podporoval legitimitu komunistické strany. Hrubý se ptá: „Co v jejich bytostech při stalinských fanfárách tak silně rezonovalo" (Hrubý 2018, 146)? Současně však dodává, že málokdo tehdy skutečně věděl, pro co se rozhoduje. Byly pro to silné intelektuální i citové důvody. Slovy Evy Kantůrkové: Člověka neformují programy, ale prožitky a vliv a přitažlivost zajímavých lidí. Při budování nového světa dle vzoru marxismu-leninismu bylo stále zřejmější, že bude třeba postupovat tvrdě proti těm, kdo se stavěli do cesty. „Když se kácí les, neptej se sekyry na svědomí! A že se tehdy kácelo - až hlavy praskaly..." (Hrubý 2018, 150).

Hrubý zdůrazňuje, že komunistické režimy však netvořili zločinci, nýbrž nadšenci, kteří věřili, že našli jedinou cestu do ráje. Mnohých se zmocnilo nadšení pro Lenina. Fakticky to bylo nadšení pro ideu osvobození $\mathrm{z}$ útlaku. $\mathrm{V}$ té době se však nevědělo o krvavé vládě jedné strany. Brutalita stalinské diktatury se pečlivě zakrývala či ospravedlňovala. Už sám Lenin hlásal po válce sovětské mládeži: „Co slouží třídnímu boji proletariátu, to je dovoleno, to je morální.. . Násilí je právem proletářské demokracie" (Hrubý 2018, 35). Když takové zprávy o násilí začaly prosakovat, převážilo nadšení a vděčnost nad realizací revoluční ideje. Karel Toman to vyjádřil verši obdivujícími Lenina: Krev prolil? Vraždil? Ano. - Ale vdechl víru... (Hrubý 2018, 123).

Po skončení druhé světové války se vedl spor o politickou a kulturní orientaci Československa. Nedůvěra v západní mocnosti, daná mnichovskou zradou, nahrávala těm, kdo prosazovali východní směřování republiky. Sympatie k Sovětskému svazu vzbudila skutečnost, že skoro celou republiku osvobodila Rudá armáda; tím Sověti prokázali nejen bojovou převahu, ale i sílu svého hospodářství organizovat vojenské tažení. V nadšení nad osvoboditeli, připomíná Hrubý, se rodila sympatie pro jeho politické a společenské zřízení. Zaujetí pro novou cestu a politická nezkušenost snižovaly kritičnost a umožnily blouznivé nadšení pro leninskou utopii. Nelze se tak divit, že mnozí vítali politickou záštitu Sovětského svazu. Zatímco zklamaní komunisté z druhé poloviny třicátých let zavrhli dosavadní průběh revoluce a rozpoznali, že sovětská cesta nevede do „nového světa“, mladí komunisté poválečného Československa považovali sovětskou cestu za nadále platnou. Intelektuálové v celé Evropě sympatizovali po válce s radikální levicí. Počátkem padesátých let se orientace 
Československa na Východ stala již závaznou oficiální politikou. Ve všech oblastech byla mohutně upřednostňována sovětská kultura a nátlak v tomto směru na obyvatelstvo byl obrovský (Hrubý 2018, 60).

I když Stalin a jeho československý slouha Gottwald zemřeli v březnu 1953, bacil cynického stalinismu nadále působil. V roce 1953 byly rozsáhlé společensko-politické změny dokonány a veškerá moc již spočinula v rukou KSČ - strana zcela srostla se státem, který plnil její vůli. Veškerý vývoj politických a společenských institucí, jakož i nový hospodářský systém byl řízen ideologií KSČ. Státní doktrínou se stal marxismus-leninismus. Společnost byla rozdělena na ty, kdo režim podporovali, či k němu byli lhostejní, a na ty, kteří vůči němu byli skeptičtí či rezistentní.

Hrubý přesně postřehl, jak mohutně režim působil ve smyslu překonání této společenské rozpolcenosti; již záhy režim rozvinul rozsáhlou propagandistickou a výchovnou kampaň (Hermann 2020, 7), včetně perzekucí a zastrašování. Diktatura se pokoušela vedle systémových změn také o změnu subjektivní identity obyvatelstva - šlo jí o vytvoření nového socialistického člověka. Pracovalo se na myšlenkové a hodnotové uniformitě jediného správného světonázoru. Lidé se tak dostávali nejen pod mohutný vnější tlak, ale rovněž byli v konfliktu se svým svědomím, jež se ř́́dilo jinými hodnotami, než vyžadoval „pokrokový“ komunistický systém. Ještě po druhé světové válce „převažovala v Československu stále ještě křest’anská a osvícenská morálka, které byly svou podstatou univerzalistické, tj. spojovala je úcta $\mathrm{k}$ člověku, k jeho důstojnosti a stejnému výkladu práva platnému pro všechny" (Hrubý 2017, 82). Po únoru 1948 se začala prosazovat selektivní morálka, která právo a důstojnost přiznala jen stoupencům komunismu. Ostatní byli posuzování podle ideologických kritérií, např. podle třídní příslušnosti. Padesátá léta pak provázejí mohutné čistky $\mathrm{v}$ podnicích a ve školách, $\mathrm{v}$ úřadech a $\mathrm{v}$ armádě či bezpečnostních složkách. Nastartované politické procesy vyústily v hrdelní rozsudky, které se týkaly zprvu těch, kdo stáli mimo komunistickou stranu a poté i těch, kdo byli ve straně.

Hrubý rovněž upozorňuje na méně připomínané plzeňské protesty, které vypukly v roce 1953, ale brzy byly potlačeny (Hrubý 2018, 57). Tyto protesty vhodně ilustrují složitost komunistického puče a současně svědčí o prostředí, z něhož Karel Hrubý pocházel. Plzeňské protesty byly zaměřeny proti státní politice a požadovaly politickou svobodu a obnovu demokracie. Není divu, že se je snažil totalitní režim utajovat. $V$ těchto protestech měli totiž rozhodující slovo právě dělníci (dělnická třída), kteř́ viděli, že bolševická cesta nevede $\mathrm{k}$ diktatuře proletariátu, ale k diktatuře byrokratického aparátu - a často právě proti proletariátu samému. Dělnictvo zde bylo silně přesvědčeno o tom, že parlamentární demokracie 
je nutným předpokladem k realizaci socialistického programu. Současně nebyl na Plzeňsku tak silný obdiv k SSSR jako za demarkační linií (Plzeň osvobodili Američané) a na východě republiky; nicméně mnozí přesto viděli v Sovětském svazu ochránce před německou rozpínavostí. Celková rezistence a nechut' se identifikovat s komunistickou ideologií zde byla poměrně silná, i když byla skrytá a překryta formální či rituální participací na komunistických akcích (Hrubý 2018, 62).

\section{Ideologizace společenských věd}

Hrubý svými texty připomíná, že zápas o identitu nového státu (a nového člověka) vedl komunistický režim od roku 1948 i na poli společenských věd, zejména historiografie, která měla přesvědčovat obyvatelstvo o tom, že komunistický systém je jedinou perspektivou, vưči níž je jakýkoli odpor marný. V historické vědě už nešlo o poctivost a nezaujatost, ale o služebnost straně; o služebnost, jež měla bojovat proti názorům a osobám, jež byly straně nepřátelské. Komunisté se intenzivně snažili získat do svých služeb historiky, kteří by byli ochotní vykládat dějiny v duchu marxisticko-leninské ideologie. Hrubý konstatuje, že tento ideologický tlak na společenské vědy měl drastické následky.

Hrubý popisuje, jak byla celá generace nemarxistických historiků vypuzena z vysokých škol a vědeckých pracovišt', byli ve většině případů zbaveni možnosti vědecky publikovat. „Přišly prověrky na pracovištích, na vysokých školách. Nevylučovala Strana, ale včerejší kolegové, proměnění v nemilosrdné soudce" (Hrubý 2018, 46). Mimořádné ztráty to způsobilo pro vzdělávání nových badatelů, nebot' zkušení nemarxističtí historici se ocitli mimo akademické instituce. Na místo zkušených historiků nastoupila generace odborně nezralá, ale politicky uvědomělá a konformní. Nejprudší útoky na „buržoazní historiografii“ probíhaly v letech 19481962 (Hrubý 2018, 66). Historiografie měla ospravedlňovat vedoucí úlohu KSČ coby nejprozíravější složky společnosti a dějin.

V zájmu boje za lepší společnost bylo zapotřebí zatočit především s „masarykismem a sociáldemokratismem“. Masaryk, který se mezi obyvatelstvem stále těšil mimořádnému respektu, byl vykreslován jako nepřítel nového režimu (Hrubý 2018, 77). Sám Masaryk se od počátku svého presidentování intenzivně a úspěšně věnoval oslabování politického vlivu Moskvy na československé komunisty, čímž snížil celkový počet jejich členů. Není proto divu, že si komunisté s Masarykem po válce vyrovnávali účty. 0 tom svědčí vypracované Dokumenty o protilidové a protinárodní politice T. G. Masaryka (Praha 1953), kde byl Masaryk vylíčen jako válečný podněcovatel a organizátor protisovětské vojenské intervence. Ideologii 
masarykismu tito historiografové vydávali za „nejutkvělejší buržoazní ideologii“, která rozvracela nový život v republice. Šlo jim o to, vyvrátit legendu o presidentu osvoboditeli a tvůrci samostatného státu, jakož i ukázat Masaryka jako oporu mezinárodní reakce proti SSSR a agenta dohodových imperialistů. Celkově komunističtí historici líčili Masaryka kritickým a nenávistným způsobem (Hrubý 2018, 78).

S menší intenzitou se titíž historici zapojili do boje proti sociálně demokratickým idejím. Zřetelným úkolem režimu bylo ukázat v nepříznivém světle politiku tehdejších západoevropských sociálně-demokratických stran, které měly silně protikomunistický kurz, a Socialistické internacionály. Často se zapomíná, že původní sociální demokraté byli úhlavními nepřáteli komunistů; mnozí sociální demokraté byli zlikvidováni ve vězení jako političtí vězni v padesátých letech (Hrubý, 2017). Hrubý připomíná, že komunisté tehdy mluvili o sociální demokracii jako o rozbíječské a zrádcovské straně a spojovali je s fašisty navzdory tomu, že mnozí byli nacisty vězněni.

Další ideovou frontu otevřeli komunisté na poli náboženství. Šlo o boj proti církvi. Tento boj se nevedl na poli Československého časopisu historického jako v prrípadě „masarykismu a sociáldemokratismu; těžiště tohoto boje proti „náboženskému tmářství“ bylo v rukou Státní bezpečnosti (StB), jež zorganizovala řadu procesů především proti katolickým duchovním. Ideologicky byl tento protináboženský boj veden ani ne tak historiky, ale spíše marxistickými filosofy a vědeckými ateisty.

Kritiku svých pozic komunisté považovali za projev „třídního nepřátelství" vůči jejich spásonosnému politickému programu, a její nositele potlačovali a ničili. Nepřítel pro ně byl vždy méně člověkem a bylo možné s ním zacházet jako s věcí, bylo-li to pro stranu výhodné, mohli jej i zlikvidovat. „Motivem identifikace s komunistickou stranou, jejím programem a ideologií bylo vždy nepřátelství k zavedeným systémům hospodářským (kapitalismu), politickým (k parlamentní demokracii stejně jako k fašistickým režimům) a k nerovnosti sociální, která je provázela. Vedle touhy po seberealizaci šlo též o potřebu sdružit se se stejně orientovaným kolektivem, o vytvoření homogenního ,my', spojeného společnou vírou, o zapojení se do jeho aktivit“ (Hrubý 2018, 189). Právě takováto „kolektivizace svědomí podle Hrubého pomáhala ohlušit vlastní svědomí. Co však způsobilo, že ti, kdo vyrostli v duchu evropské civilizace, ztratili ze zřetele důstojnost člověka, jakmile byl označen za třídního či politického nepř́itele? Hrubý ukazuje, že léta války a nacistické okupace představovala pro mnohé obyvatele výraznou zkušenost, která vytvářela černobílé vidění světa - nepřítel byl jasně určen. „Stáli jsme proti nepříteli s veškerou vášní, jakou může člověk mít. ... byl tu jasný cíl: nepřítele zlikvidovat" (Hrubý 
2018, 148). Prostřednictvím této zkušenosti lze porozumět radikálnosti válečné generace, jež si svou radikální mentalitu nesla i do poválečných let. Šlo o nový řád hodnot, novou interpretaci světa. Násilí bylo ospravedlněno vyšším cílem, historickou nutností. Mnozí zůstávali ve straně, nebot' věřili, že ji mohou polidštit. Hrubý v této souvislosti konstatuje, že jsme odpovědní i za to, čemu věříme, a proto není víra argumentem proti vině (Hrubý 2018, 37).

\section{Procitající intelektuálové}

Období mezi léty 1956 a 1966 se podle Hrubého vyznačovalo náročným zápasem procitajících intelektuálů s centrem moci - šlo především o uvolnění cenzury a byrokratických pout (Hrubý 2018,197). Nejpozoruhodnějším př́kladem odvážné revize dogmatického marxismu-leninismu je pro Hrubého filosof Karel Kosík. Jeho Dialektika konkrétního (1963) byla nejen kritickou revizí marxismu (o jehož životnosti v původní intenci byl Kosík stále přesvědčen), ale rovněž pokusem stanovit nové perspektivy socialistického humanismu. Kosík se tak proměnil z fanatika třídní nenávisti a stoupence stalinsko-gottwaldovské politiky v kritického filosofa humanistického marxismu, jenž svými myšlenkami ovlivnil dění vedoucí k pražskému jaru. V roce 1968 požadoval názorovou pluralitu, čímž chtěl zabránit tomu, aby se z marxistické filosofie stala ideologie. Poukazoval na to, že strana sklouzla do bahna dogmatu a nelidskosti. Kromě toho Hrubý staví Kosíkovy analýzy především vedle prací Masaryka, Rádla a Patočky (Hrubý 2018, 243).

Po odhalení stalinských zločinů se mnozí komunisté probudili z opojného snu a začali chápat, že socialismus nelze budovat zcela bez demokracie. Proto se v šedesátých letech pokusili o obnovu některý demokratických rysů - tato „demokracie“ však stále zůstávala v zajetí leninské ideologie (Hrubý 2018, 38). Hrubého studie ukazují, jak se od stalinismu vraceli k Leninovi, aniž však tušili, že právě Lenin byl zakladatel neomezené moci a iniciátor masových likvidací nepřátel. „Revoluční přeměna světa vyžadovala podle Lenina účelové hodnocení. To vůdce světového proletariátu vyjádřil zcela nezaobaleně v projevu k sovětské mládeži ve dvacátých letech, kde stranický ,dorost' učil základnímu principu komunistické ,morálky', podle něhož všechno, co slouží třídnímu boji proletariátu, je dovoleno, je morální, ba pod zorným úhlem cíle je dokonce záslužné. Co tento boj brzdí a odmítá, je třeba vymýtit, zničit. Násilí je tak podle Lenina „právem‘ proletářské demokracie“ (Hrubý 2017, 82). Zatímco Lenin posvětil teror především vůči kapitalistům, Stalin z něj učinil standardní metodu své osobní diktatury (Hrubý 2018, 197). 


\section{Pražské jaro}

Šedesátý osmý rok představoval novou cestu, která však neznamenala odklon od komunismu. Šlo o opuštění stalinismu a uvolnění poměrů v rámci komunistické diktatury. Proklamované „zlidštění“ komunistického systému jej mělo především upevnit. Podle Dubčeka nebyl možný jiný socialistický program než marxistický, který je založen na společenském vlastnictví výrobních prostředků (Hrubý 2018, 95). Avšak byla to inteligence, umělci a publicisté, kdo posouval hranice reformy dále, než byla komunistická strana ochotna jít. KSČ však trvala na beztřídním uspořádání společnosti na základě marxismu-leninismu. Není divu, že společnost nebyla prosta strachu $\mathrm{z}$ návratu k dřívějším metodám persekuce. Konformita vůči socialismu tak nebyla jen výrazem lhostejnosti, ale byla rovněž taktickou nutností. Hrubého analýzy příhodně ilustrují, proč během pražského jara v žádném případě nešlo o obnovení pluralitního parlamentního systému. Navzdory prosazující se liberalizaci vnitrostranického prostředí, připuštění názorových proudů uvnitř KSČ a zrušení cenzury, měla být nadále zcela vyloučena politická opozice. Nepřekročitelná mez demokratizace byla tehdy určena jednak (a to především) začleněním Československa do sovětského bloku, a jednak neschopností komunistů opustit marxismus-leninismus. Ze zajetí z mocenského vlivu Moskvy nebylo možné vystoupit bez vojenského konfliktu.

Přesto bylo pražské jaro pozitivní v tom, že překonalo dědictví stalinismu, oslabilo některá ideologická dogmata a poskytlo snesitelnější podmínky pro nekomunisty. Stále intenzivněji se ukazovalo, že komunistický model je neudržitelný, a že je nutné obnovit alespoň některé občanské svobody. Impozantní bylo následné celonárodní vzepětí proti okupaci, jež vycházelo už nikoli tolik z obrany nového socialismu jako spíše z obrany lidské důstojnosti (Hrubý 2018, 105).

\section{Polemika s revizionisty}

Zhroucení komunistického systému vrátilo Československo k pluralitní demokracii. Lidské hodnoty se ocitly podle Hrubého pod novým tlakem. V této situaci Hrubý kriticky komentuje analýzy některých historiků soudobých dějin (např. M. Pullmann, M. Spurný - nazývaných revizionisty), kteří zkoumají dosud zanedbávanou každodennost komunistického diktatury. Diktaturu vykládají na základě nezproblematizovaného konsensu obyvatelstva, který však byl dle Hrubého předstíraný. Tato teorie každodennosti byla původně vlastní německým historikům. Zmínění revizionističtí historikové podle Hrubého svými jednostrannými pracemi zaměřenými na každodennost diktatury zpochybňují obraz teroru, který vyvstává 
ze starších prací o komunismu. Jejich pojetí relativizuje podíl politických složek při destrukci demokracie a nastolení diktatury přičítá mentalitě společnosti. Zrovna tak nevěnují dostatečnou pozornost tomu, jak zastrašující prostředky režimu formovaly každodennost. Hrubý na rozdíl od revizionistů zdůrazňuje, že předpolitický prostor každodennosti nebyl v diktatuře prost vlivu politična. Nadto takovéto pojetí společnosti jako jednoho legitimizujícího celku je dle Hrubého zavádějící, protože ve skutečnosti zde bylo více společností, jimž byly vlastní odlišné perspektivy. Některé z dané situace profitovaly, jiné nikoli. Připomíná, že právě výlučnost monopolu ve všech oblastech života státu (monopol se týkal oblasti politické, ekonomické a ideologické) nám umožňuje nazvat tento komunistický systém totalitním. A to i za předpokladu, že míra teroru byla v jednotlivých obdobích komunismu odlišná. Přesto byla totalitní struktura vlastním trvalým rysem komunistického Československa (Hrubý 2018, 284-325).

\section{Závěr}

Karel Hruhý nám prostřednictvím svého promýšlení politických aspektů dějin především druhé poloviny 20 . století umožňuje porozumět motivům a cílům této vypjaté epochy dějin $v$ souvislosti s jeho kulturně-politickou aktivitou, jíž čelil poválečné politické deviaci. Komunistické uchvácení moci a jeho sociologické a psychologické aspekty vyvstávají v Hrubého líčení s přesvědčivostí očitého svědka, který byl ukován $\mathrm{v}$ ohni četných zkoušek, do nichž jej osud nemilosrdně postavil. Sám vybaven analytickým rozumem a osobní integritou prošel zápasem s komunistickou diktaturou a vydal o něm osobní i literární svědectví, jež nám pomáhá se duchovně zorientovat $\mathrm{v}$ přítomnosti a rozpoznávat tendence, které jsou kdykoli ochotny ponížit člověka tím, že jej zbaví důstojnosti a svobody. Hrubý dnešku připomíná, že nejnaléhavější českou otázkou současnosti je postavit proti stranickému, národnímu, třídnímu nebo rasovému partikularismu etický a právní univerzalismus. „Potřebujeme nový typ občanství, občanství politického a humanitního, které není zaslepeně podřízeno loajalitě jen národní, tř́ídní či skupinové, nýbrž loajalitě k zásadám pravdy, svobody, spravedlnosti, demokracie a tolerance" (Hrubý 1997b, 32).

\section{Literatúra}

HRUBÝ, K. (1997a): Dialog Charty 77 s exilem. In: Císařovská, B. - Drápala, M. Prečan, V. - Vančura, J. (eds): Charta 77 očima současníků. Po dvaceti letech. Praha: Ústav pro soudobé dějiny AV ČR, Doplněk, 46 - 54.

HRUBÝ, K. (1997b): Naše dnešní otázky. In: Eva Broklová (ed.): Sto let Masarykovy České otázky. Praha: Ústav T. G. Masaryka, 27 - 33. 
HRUBÝ, K. (2014): Žijeme ve slabé společnosti (rozhovor s A. Prázným). In: Lidové noviny, 24. 10. 2014, 13 - 14.

HRUBÝ, K. (2017): Mohlo to být horší. Usmířené vzpomínání na komunistický kriminál. Praha: ÚSD AV ČR.

HRUBÝ, K. (2018): Cesty komunistickou diktaturou. Kritické studie a eseje. Praha: Argo - ÚSD AV ČR.

HRUBÝ, K. (2015): Jsou jisté hodnoty, které nemůžeme vzdát. In: Grygarová, D. Hermann, T. - Kostlán A. - Petráň, T. (eds.): Homines scientiarum I. Třicet př́běhů české vědy a filosofie. Praha: Ústav pro soudobé dějiny AV ČR, Pavel Mervart, $99-155$.

HERMANN, T. (2020): Marxismus-leninismus a komunistická výchova. In: Cuhra, J. - Černá, M. - Devátá, M. - Hermann, T. - Kourová, P. Pojetí a prosazování komunistické výchovy v Československu (1948-1989). Praha: Ústav pro soudobé dějiny AV ČR, 7 - 30.

HOPPE, J. (2009): Opozice '68. Sociální demokracie, KAN a K 231 v období Pražského jara. Praha: Prostor.

KREJČÍ, J. (2006): Mezi demokracií a diktaturou. Domov a exil. Praha: Masarykův ústav - Archiv AV ČR, Albis International.

TOMEŠ, J. (2005): Průkopníci a pokračovatelé. Osobnosti v dějinách České sociální demokracie 1878-2005. Praha: ČSSD.

doc. PhDr. Aleš Prázný, Ph.D.

Univerzita Pardubice

Studentská 95

53210 Pardubice 2

ales.prazny@upce.cz 